\title{
Beta-cell replacement for treatment of severe hypoglycemia: long-term comparison between islet-kidney vs. pancreas-kidney transplantation
}

\author{
Lehmann, Roger
}

Article based on the Somogyi Award Lecture 2018

\begin{abstract}
summary
Michael Somogyi showed 1951 that a hypoglycemia induces a higher glucose response after a glucose load. Due to a lack of continuous glucose monitoring it was assumed that a high glucose level in the morning was a sign of nocturnal hypoglycemia. This phenomenon was therefore named after the author, the Somogyi effect. In modern times with continuous glucose measurement it was becoming apparent that fasting plasma glucose below $5 \mathrm{mmol} / \mathrm{l}$ indicated in $94 \%$ of cases an undetected hypoglycemia during the night, but the same number of patients had a fasting plasma glucose above 5 mmol/I with nocturnal hypoglycemia. If the fasting glucose, however, was above $5 \mathrm{mmol} / \mathrm{l}$, the majority of cases with an elevated pre-breakfast glucose level (57\%) was caused by the Dawn phenomenon, a surge of insulin antagonists during the night (growth hormone) or early morning hours without any hypoglycemia during the night. Taken all glucose levels in the morning into account, about one quarter is due to the Somogyi effect and three quarters due to the Dawn phenomenon. Thus, the so called Somogyi phenomenon was much rarer than previously suspected (28\%). In this review we analyzed how hypoglycemia can be prevented with beta-cell replacement (islet or pancreas transplantation). Our own experience demonstrated that severe hypoglycemia could be reduced by more than $95 \%$. In addition to avoid severe hypoglycemia the chance to protect the transplanted kidney from loss of function in a setting of simultaneous islet-kidney or pancreas-kidney transplantation was the same in islet and in pancreas transplantation despite the need of additional small insulin doses and the rate of complications and reoperations was significantly less in islet vs. pancreas transplantation.
\end{abstract}

- Key words: hypoglycaemia, Somogyi effect, dawn phenomenon, continuous glucose monitoring, islet/ pancreas-kidney transplantation

\section{Béta-sejt-pótló kezelés a hypoglykaemia kezelésére. A szigetsejt-vese, illetve a pancreas-vese transzplantáció hosszú távú eredményeinek összevetése}

Összefoglalás: Somogyi professzor 1951-ben igazolta, hogy a vércukoresést követö ismételt glukózterhelés a vártnál nagyobb vércukor-emelkedést eredményez. Folyamatos vércukor-monitorozás hiányában feltételezte, hogy a reggel, ébredéskor mèrt magas vércukorszint éjszakai hypoglykaemia következménye. A posthypoglykaemiás hyperglykaemiát elsö leirójáról Somogyi-jelenségnek nevezték el. Napjainkban folyamatos szöveti cukorméréssel igazolható volt, hogy a reggel mért $<5,0$ mmol/1-es vércukorszint az esetek 94\%-ában észrevétlen éjszakai hypoglykaemiát jelez, legalább ilyen gyakorinak bizonyult azonban, hogy éjszakai/hajnali vércukoresést követöen a reggel mért vércukor még 5,0 mmol/l fölötti maradt. E vizsgálatok arra is fényt deritettek, hogy a reggeli magasabb (>5,0 mmol/1) vércukorszinttel rendelkezök többségénél (57\%ánál) nem alakult ki éjszakai vércukoresés, az emelkedést a contrainsularis hormonok (elsösorban a növekedési hormon) hajnali-kora reggeli szekréciós csúcsa okozza (hajnalijelenség). Az eredmények együttes értékelésével megállapitható, hogy az éhomra mért magasabb vércukorszint csak az esetek negyedében irható a Somogyi-hatás számlájára, 3/4-e a hajnali 
jelenség következménye. A Somogyi-hatás tehát sokkal ritkább (28\%) a korábban feltételezettnél. A jelen összefoglaló közlemény részletesen bemutatja, hogy hogyan elözhetö meg nem kivánt vércukoresések elöfordulása béta-sejt-pótló kezeléssel (szigetsejt- vagy pancreas-transzplantáció). Saját megfigyeléseink szerint e módon a súlyos vércukoresések mintegy 95\%-a elkerülhetö. Egyidejüleg végzett szigetsejt-vese, illetve pancreas-vese átültetés esetén további elönyt jelent a vesemüködés további romlásának megállitása még akkor is, ha kis adag inzulin adása a beavatkozást követöen is szükséges marad.

Kulcsszavak: hypoglykaemia, Somogyi-jelenség, hajnali jelenség, folyamatos cukorszint-monitorozás, szigetsejt/pancreas-vese átültetés

Abbreviations:

CKD-EPI: chronic kidney disease epidemiologic collaboration; GFR: glomerular fgiltgration rate; IAK: islet after kidney (transplantation); IEQ: islet equivalent; ns: non significant; PAK: pancreas after kidney (transplantation); SIK: simultaneous isletkidney transplantation; SPK: simultaneous pancreas-kidney transplantation

\section{Introduction}

Both transplantation of isolated islets of Langerhans as well as whole organ pancreas transplantation are treatment options in the care of patients with type 1 diabetes mellitus. However, there is only few data regarding their long-term effect, in particular when compared to each other.

Michael Somogyi showed 1951 that a hypoglycemia induces a higher glucose response after a glucose load. ${ }^{1}$ Due to a lack of continuous glucose monitoring it was assumed that a high glucose level in the morning was a sign of nocturnal hypoglycemia. This phenomenon was therefore named after the author, the Somogyi effect. In modern times with continuous glucose measurement it was becoming apparent that fasting plasma glucose below $5 \mathrm{mmol} / 1$ indicated in $94 \%$ of cases an undetected hypoglycemia during the night, but the same number of patients had a fasting plasma glucose above $5 \mathrm{mmol} / \mathrm{l}$ with nocturnal hypoglycemia. If the fasting glucose, however, was above $5 \mathrm{mmol} / \mathrm{l}$, the majority of cases with an elevated pre-breakfast glucose level $(57 \%)$ was caused by the Dawn phenomenon, a surge of insulin antagonists during the night (growth hormone) or early morning hours without any hypoglycemia during the night. Taken all glucose levels in the morning into account, about one quarter is due to the Somogyi effect and three quarters due to the Dawn phenomenon. ${ }^{2}$ Thus, the so called Somogyi phenomenon was much rarer than previously suspected $(28 \%)$. This review article focused on the avoidance of severe episodes of hypoglycemia by beta-cell replacement.

Pancreas transplantation has been conducted for more than 50 years, ${ }^{3}$ islet transplantation emerged as an alternative to whole organ transplantation mainly after the publication of results with consistent insulin independence using a steroid-free immunosuppression protocol in the year $2000 .{ }^{4}$ The results of islet transplantation and the metabolic effects of successful islet transplantation were already described before. ${ }^{5,6}$ Both transplantation options can be conducted alone or in combination with a kidney. Whereas simultaneous pancreas-kidney transplantation (SPK) is an intervention with proven benefits in terms of surviv$\mathrm{al}^{7}{ }^{7}$ conflicting results in pancreas transplantation alone have been published. ${ }^{8,9}$

By providing a source of endogenous insulin secretion, both transplantation options aim at improving glycemic control. Yet, while insulin independence is routinely achieved in pancreas transplantation and is still present in $60-70 \%$ of patients 5 years after transplantation, ${ }^{10}$ recipients of islet transplantation need more than one transplantation to achieve insulin independence in most cases and insulin independence is lost in more than $70 \%$ after 2 years. ${ }^{11}$ However in a selected study the insulin independence rate at 5 years with modern immunosuppression (anti-TNF $\alpha$ treatment) was the same in islet and pancreas transplantation. ${ }^{12}$ On the other hand, the rate of complications is high in pancreas transplantation with up to $40 \%$ of patients undergoing relaparotomy during 
the first 3 months, ${ }^{13}$ whereas laparotomy rate in islet transplantation is as low as $3 \% .^{11}$

Data on transplantation outcome of SPK transplantation directly compared to simultaneous islet-kidney (SIK) transplantation is rare. We reported a 5 year follow-up of SPK vs. SIK transplantation, ${ }^{14}$ and a comparison of pancreas vs. islet transplantation alone was presented recently, but this study did not include information on glycemic control. ${ }^{15}$

Therefore, the aim of our transplant center was to compare SPK and SIK transplantation conducted at a single center with regard to glycemic control and transplantation related complications as well as function of the transplanted kidney over more than 10 years.

\section{Technique and principles of simultaneous islet or pancreas and kidney transplantation}

\section{Organ procurement and surgical procedures}

Kidneys and pancreata were obtained from braindead multi-organ cadaver donors from different hospitals in Switzerland. A negative serum cross-match between donor and recipient and AB0 compatibility was required. Organs of donors were preferentially allocated to recipients of a comparable age.

The transplantation of the pancreas was performed heterotopically into the abdomen. Portal drainage was applied through venous anastomosis between the pancreas and the patient's superior mesenteric vein. The arterial access of the transplant was connected to the common iliac artery. All patients received an exocrine enteric drainage.

Pancreatic islets are micro-organs with nerve and blood supply with a diameter between 50 and 400 $\mu \mathrm{m}$ consisting of alpha-, beta-, delta-cells, and other endocrine cells producing different hormones and peptides. These islets represent about $2 \%$ of the total pancreas weight, which corresponds to about 2 gr of mass. About $50 \%$ of the cells in the islets consists of insulin producing beta-cells. The isolation of these islets from the intact pancreas happens in two major steps:

1. Collagenase digestion by injection of the enzyme in the pancreatic duct and
2. density-gradient purification separating islets from the heavier, and more abundant exocrine tissue. The first transplantation of islets was done by David Sutherland 5 in Minneapolis in the year 1974 and the first European islet transplantation was done in 1978 in Zurich, Switzerland by Felix Largiadèr. ${ }^{16}$ The modern human isolation method was invented and developed by Camillo Ricordi and first published in $1988 .{ }^{17}$

Preparation and transplantation of the pancreatic islets today is still similar to the original protocol and were performed as previously described. ${ }^{18}$ Transplanted islets were not cultured before transplantation. Islet transplantation was conducted by open approach, if performed together with a kidney transplantation, and by transhepatic percutaneous approach in all other cases. Islet volume is given as islet equivalents (IEQ). ${ }^{19}$

The kidney transplantation was performed in the same way in all patients by heterotopical transplantation of the graft into the right or left iliac fossa and connection of the renal vein and artery to the iliac vessels.

Heparin was administered in all patients starting 4 hours after transplantation (10,000 units per day). In addition, 70 units of heparin per kg recipient weight (but not more than 5000 units in total) were added to islet preparations prior to infusion.

\section{Immunosuppression}

In the SPK group, a regimen with tacrolimus ${ }^{20}$ and mycophenolate mofetil, ${ }^{21}$ as well as prednisone was used. Induction therapy was performed initially with basiliximab and after 2012 with thymoglobuline. ${ }^{22}$ Target long-term trough levels for tacrolimus were 10-15 $\mu \mathrm{g} / \mathrm{l}$. Mycophenolate mofetil was administered weight adapted twice daily in doses of $720-1440 \mathrm{mg}$.

In the SIK group, immunosuppression was carried out with tacrolimus and sirolimus according to the Edmonton protocol. ${ }^{4}$ Target long-term trough levels were 7 to $10 \mu \mathrm{g} / \mathrm{l}$ for sirolimus and 3 to $6 \mu \mathrm{g} / \mathrm{l}$ for tacrolimus. Sirolimus was later changed to mycophenolate mofetil due to the high rate of side effects reported for sirolimus. ${ }^{11}$ Induction therapy was performed initially with daclizumab, after 2012 with thymoglobuline ${ }^{23}$ or basiliximab) for retransplantation. 
For patients receiving pancreas or islet transplantation after kidney transplantation (PAK or IAK), immunosuppression was similar as compared to simultaneous transplantation with the exception of induction therapy, where thymoglobuline was replaced by basiliximab.

\section{Follow-up}

During follow-up, pancreas or islet transplant function was assessed by $\mathrm{HbA}_{1 \mathrm{c}}$ measurement and need for exogenous insulin. In SIK/IAK recipients, C-peptide secretion was measured during a mixedmeal tolerance test at least every year after transplantation. ${ }^{18}$ Because of the high rate of insulin independence, C-peptide was not routinely measured after SPK. Renal function was assessed by serum creatinine and GFR estimated by the CKDEPI formula. ${ }^{24}$ Patients were seen at least every 6 months for evaluation of transplant function and adverse events. All patients were treated according to current international guidelines. In particular, insulin treatment after transplantation, if necessary, was carried out with the same regimen and intensity as before transplantation. Insulin therapy was initiated when $\mathrm{HbA}_{1 \mathrm{c}}$ levels increased above $6.0 \%$ or fasting glucose was repeatedly measured above $7.0 \mathrm{mmol} / \mathrm{l}$, starting with low-dose basal insulin (4-8 units). The amount of insulin needed was documented by calculating mean daily insulin dosages from patient logs.

\section{Relevance of hypoglycemia}

The Diabetes Control and Complication Trial demonstrated 25 years ago that a better glycemic control reduced the microvascular complications

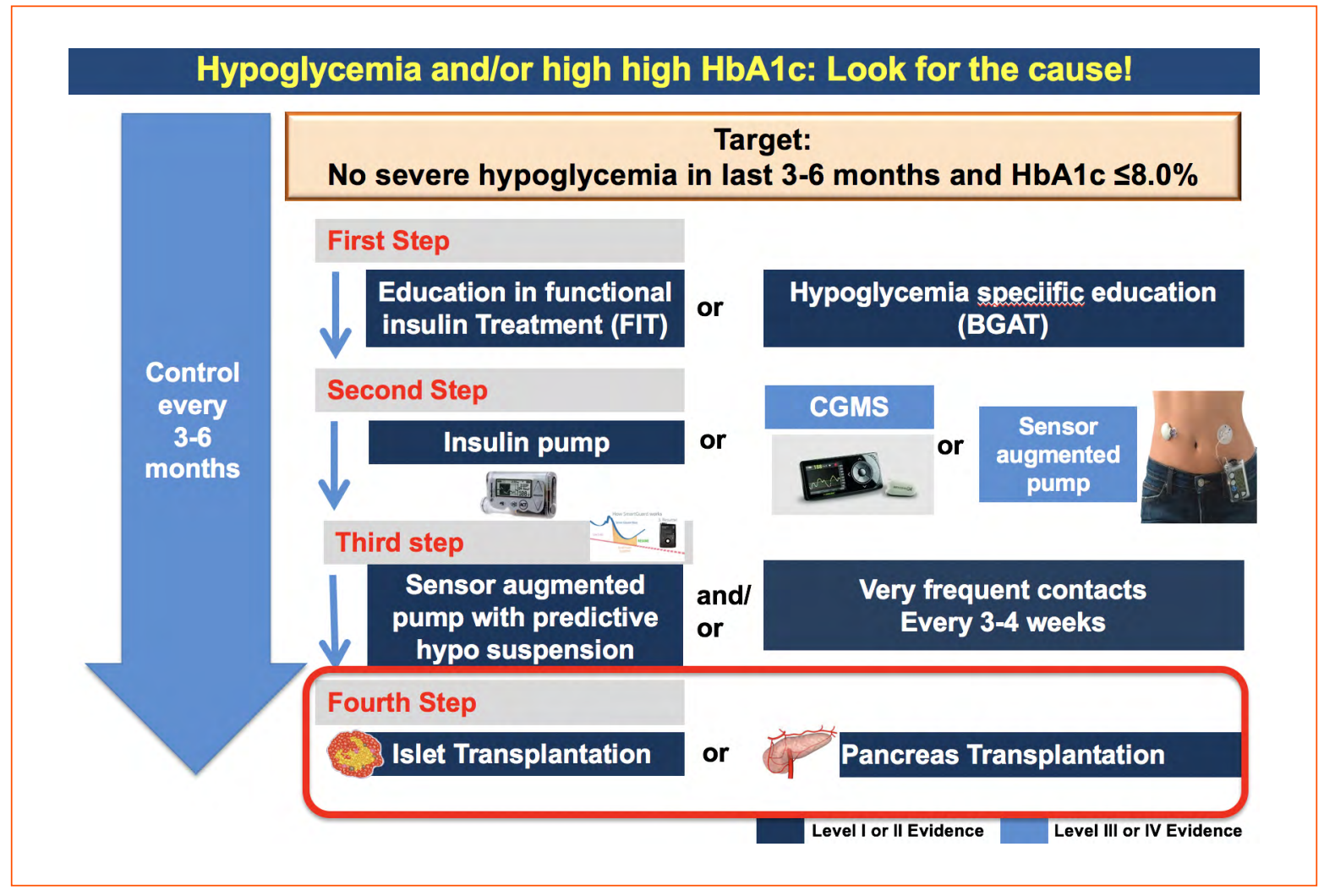

Figure 1. Evidenced based treatment strategies in patients with type 1 diabetes mellitus and severe episodes of hypoglycemia as reported by an international expert group 
of type 1 diabetes mellitus considerably, but at the same time the rate of severe hypoglycemia increased. ${ }^{25}$

How common is severe hypoglycemia today? It is estimated that the rate is about 1.1 to 3.5 severe hypoglycemia per patient-year, which means that about $30 \%$ of patients with type 1 diabetes have an episode of severe hypoglycemia per year. In European countries the prevalence of type 1 diabetes is about $0.3 \%$ of the population which means that $0.1 \%$ of the population have at least one severe episode of hypoglycemia. By taking the low organ donation rate of about $10-35$ per million people into account and that only $50 \%$ of the pancreata offered can be used for beta-cell replacement, only about $1-2 \%$ of patients with severe hypoglycemia can be transplantated. ${ }^{26}$ This together with the need for life-long immunsuppressen is the reason why islet or pancreas transplantation is not considered the first line of treatment in type 1 diabetes mellitus, but as $4^{\text {th }}$ line treatment of severe hypoglycemia (Figure 1).

\section{Results of islet and pancreas transplantation}

The 5-year experience in our center published in 2008 showed that kidney transplantation alone without beta-cell replacement was not able to improve $\mathrm{HbA}_{1 \mathrm{c}}$ below 8\%, and that kidney function 5 years after kidney transplantation alone vs. pancreas-kidney and islet kidney transplantation was not different. Relaparatomies due to complications of the transplanted pancreas, however, was $44 \%$, whereas in islet transplantation in was $0 \% .^{27}$ Therefore, we proposed in 2008 a new goal for islet transplantation, which is now universally accepted, namely avoidance of severe hypoglycemia and good glycemic control with a $\mathrm{HbA}_{1 \mathrm{c}}$ below $7.0 \%$ in order to prevent damage to the transplanted kidney and micro- and macrovascular disease. ${ }^{28}$

\section{Prospective 13-year follow-up study in simultaneous islet-kidney vs. pancreas-kidney transplantation}

Since long-term follow-up is needed to assess kidney function after combined islet- or pancreas-kidney transplantation, our transplant center published the longest single center follow-up of simultaneous islet-kidney vs. pancreas kidney transplantation in $2015 .{ }^{29} 94$ patients with SPK/PAK were compared with 38 patients with SIK/IAK over a period of up to 13 years.

\section{Patient selection for transplantation}

Based on the small number of possible transplants for beta-cell replacement and the need for life-long immunosuppression, patients with type 1 diabetes mellitus and end-stage renal failure with need for dialysis treatment who were referred to our institution for the evaluation of possible renal transplantation were considered for combined transplantation. Malignant disease, chronic infection, advanced heart disease, severe liver damage or non-compliance were general contraindications for transplantation. Patient selection for one of the two protocols of combined transplantation was performed after careful evaluation of possible advantages and disadvantages, with special regard to age and comorbidities. Older patients with many - in particular cardiovascular - comorbidities who were considered to be at higher risk of intra-operative complications were preferentially assigned to the less invasive procedure of islet transplantation, while younger and healthier patients were offered both modalities.

Patients receiving SIK/IAK transplantation were significantly older and had a longer duration of diabetes before transplantation. However, age at diagnosis was not different between the two groups. Diabetes related complications were common in patients before transplantation (Table 1). In addition to end-stage renal disease, which was present in all patients, more than $95 \%$ of patients suffered from retinopathy, and more than $80 \%$ from peripheral and/or autonomic neuropathy. $69 \%$ of SIK/IAK recipients and $77 \%$ of SPK/PAK recipients suffered from at least one episode of severe hypoglycemia in the preceding year (ns).

Before transplantation, coronary heart disease was present in $\sim 50 \%$ of patients, with a tendency towards higher frequency in SIK/IAK recipients (63\% vs. $47 \%$ in SPK/PAK recipients, $\mathrm{p}=0.06$ ). Known cerebrovascular disease was present in 15$25 \%$ of patients, and peripheral vascular disease 
Table 1. Baseline and transplantation related characteristics of patients included in the study

\begin{tabular}{|c|c|c|c|}
\hline & SPK/PAK & SIK/IAK & p-Value \\
\hline Patients included ( $\mathrm{n})$ & 94 & 38 & - \\
\hline Female gender (\%) & 52.1 & 50.0 & 0.83 \\
\hline Age at transplantation (y) & $44.2 \pm 7.6$ & $51.8 \pm 9.0$ & $<0.001$ \\
\hline Age at diagnosis (y) & $12.3 \pm 7.0$ & $14.7 \pm 10.0$ & 0.28 \\
\hline Diabetes duration before transplantation (y) & $32.1 \pm 8.2$ & $37.0 \pm 11.0$ & 0.02 \\
\hline Follow-up after transplantation (y) & $5.6 \pm 3.8$ & $6.4 \pm 3.9$ & 0.36 \\
\hline Time on waiting list (months) & $11.3 \pm 9.3$ & $17.3 \pm 14.7$ & 0.02 \\
\hline Donor age (y) & $32.6 \pm 12.1$ & $53.4 \pm 8.1$ & $<0.001$ \\
\hline Donor female gender (\%) & 66.6 & 68.9 & 0.58 \\
\hline Donor BMI (kg/m ) & $23.2 \pm 3.2$ & $25.9 \pm 2.7$ & $<0.001$ \\
\hline Cold ischemia time (minutes) & $561.2 \pm 180.6$ & $325.6 \pm 81.6$ & $<0.001$ \\
\hline Number of transplantations (n) & $\mathrm{n} / \mathrm{a}$ & $2.1 \pm 1.3$ & - \\
\hline Mean islet number/kg BW/transplantation $(\mathrm{n})$ & $\mathrm{n} / \mathrm{a}$ & $8839 \pm 7454$ & - \\
\hline Mean IEQ/kg BW/transplantation $(\mathrm{n})$ & $\mathrm{n} / \mathrm{a}$ & $11408 \pm 10380$ & - \\
\hline
\end{tabular}

Data are provided as numbers, mean \pm SD or percentage. P-Values are calculated for comparison between groups (Mann-Whitney test).

SPK: simultaneous pancreas-kidney transplantation, PAK: pancreas after kidney transplantation, SIK: simultaneous islet kidney transplantation, IAK: Islet after kidney transplantation

in about $50 \%$ of all patients. $28 \%$ of SPK/PAK recipients and $37 \%$ of SIK/IAK recipients were smokers (ns).

\section{Transplantation related characteristics}

Time on the waiting list before transplantation for SIK/IAK patients was 6 months longer than in SPK/PAK recipients $(p=0.02)$. Donors of organs for SIK/IAK recipients were about 20 years older than SPK/PAK organ donors, this was true for pancreas donors of simultaneous transplantation (SPK/SIK, age difference of $20.3 \mathrm{y}$ ) as well as donors for transplantation after kidney (PAK/IAK). BMI was higher in SIK/IAK donors compared to SPK/PAK donors $(\mathrm{p}<0.001)$. Cold ischemia time was about 2.5 hours longer in SPK/PAK vs. SIK/IAK recipients $(\mathrm{p}<0.001)$. Islet recipients received in average $2.1 \pm 1.3$ transplantations per patient, with a mean of 11,408 $\pm 10,380$ IEQ per kg body weight.

\section{Insulin independence and glycemic control}

Insulin independence was significantly higher at 5 years for SPK/PAK (74\%) compared with $9 \%$ for SIK/IAK $(\mathrm{p}<0.001)$. Nonetheless, in both groups a significant decrease of $\mathrm{HbA}_{1 \mathrm{c}}$ was observed 1 year after transplantation compared to the last
$\mathrm{HbA}_{1 \mathrm{c}}$ measured before transplantation (Figure 2). $\mathrm{HbA}_{1 \mathrm{c}}$ decreased in the $\mathrm{SPK} / \mathrm{PAK}$ group from $7.8 \pm 1.3 \%$ to $5.9 \pm 1.1 \%$ and in the SIK/IAK group from $8.0 \pm 1.3 \%$ to $6.5 \pm 1.1 \%$, respectively $(\mathrm{p}<0.001$ for both, $\mathrm{n}=126)$. $\mathrm{HbA}_{1 \mathrm{c}}$ remained stable in both groups after transplantation (mean $\mathrm{HbA}_{1 \mathrm{c}}$ during follow-up $5.8 \pm 0.8 \%$ and $6.7 \pm 1.0 \%$ for SPK/PAK and SIK/IAK, respectively), with a significant lower value (compared to pre-transplantation) until year $6(\mathrm{SPK} / \mathrm{PAK}, \mathrm{p}=0.001, \mathrm{n}=46)$ and 7 (SIK/IAK, $\mathrm{p}=0.002, \mathrm{n}=37$ ), respectively (Bonferroni correction applied, $\left.\alpha^{\prime}=0.004\right)$. In both groups, there was no time point after transplantation when $\mathrm{HbA}_{1 \mathrm{c}}$ rose significantly compared to year 1 after transplantation.

Mean $\mathrm{HbA}_{1 \mathrm{c}}$ as well as the last $\mathrm{HbA}_{1 \mathrm{c}}$ measured during follow-up in patients with a total follow-up of more than 10 years was not different compared to those with a shorter follow-up. In the SPK/PAK group, mean and last $\mathrm{HbA}_{1 \mathrm{c}}$ were $5.8 \pm 0.8 \%$ and $5.7 \pm 0.8 \%$ for patients with a follow-up $<10$ years, and $5.5 \pm 0.4 \%$ and $5.4 \pm 0.5 \%$ for patients with a follow-up $>10$ years (ns). In the SIK/IAK group, these values were $6.7 \pm 1.1 \%$ and $6.8 \pm 1.3 \%$ for a follow-up $<10$ years, and $6.5 \pm 0.8 \%$ and $6.6 \pm 1.2 \%$ for a follow-up $>10$ years (ns).

In the SIK/IAK group, C-peptide secretion was measured at 3,6 and 12 months after 


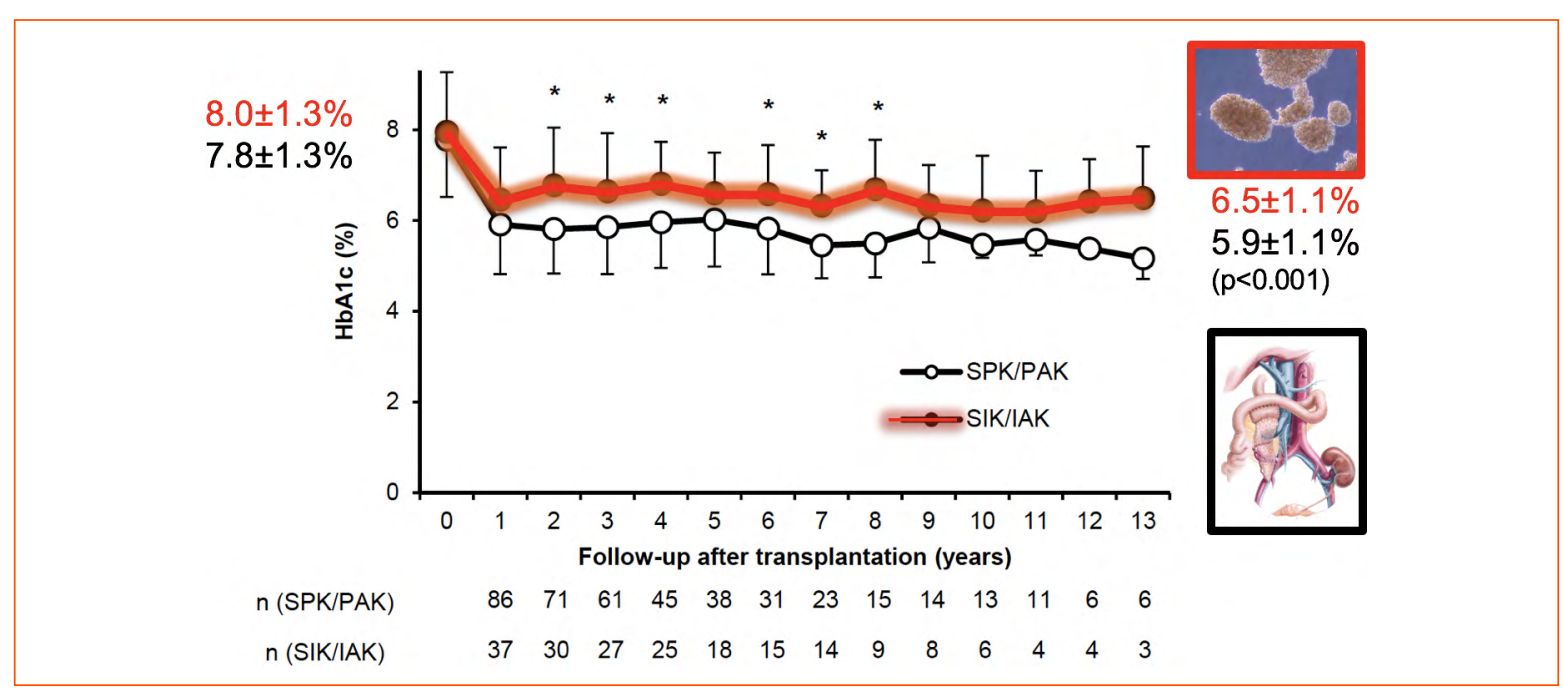

Figure 2. $H b A_{1 c}(\%)$ after Simultaneous Pancreas-Kidney/Pancreas after Kidney (SPK/PAK) or Simultaneous IsletKidney/Islet after Kidney (SIK/IAK) transplantation before ("O") and after transplantation n: number of patients observed at a particular time point after transplantation ${ }^{*} p<0.004$ (Mann-Whitney test, Bonferroni correction applied, $a^{\prime}=0.004$ )

transplantation during a mixed meal tolerance test (and yearly afterwards). There were 3 patients without $\mathrm{C}$-peptide response after transplantation in this group (defined as C-peptide $<0.1 \mathrm{nmol} / \mathrm{l}$ )
(Figure 3). The highest level of the maximally stimulated C-peptide during the post-transplant period was $1.34 \pm 1.10 \mathrm{nmol} / \mathrm{l}$, the last value measured during follow-up $1.12 \pm 1.01 \mathrm{nmol} / \mathrm{l}$.

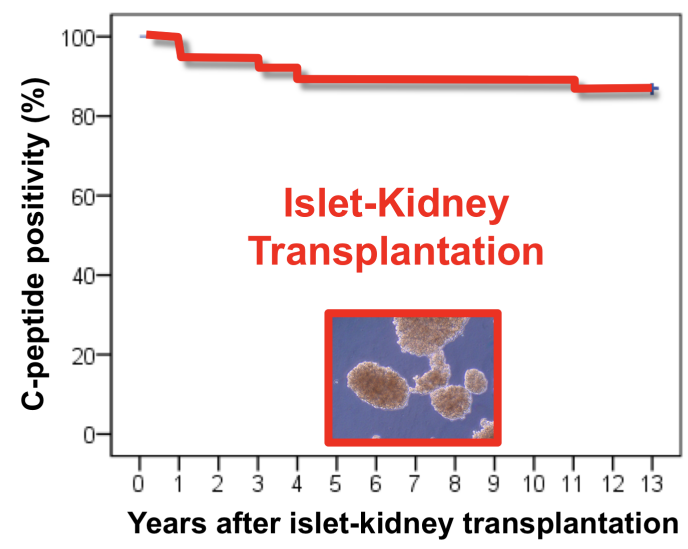

\section{$0.3-0.4 \mathrm{E} / \mathrm{kg} / \mathrm{d}=24 \mathrm{U} / \mathrm{day}=50 \%$ insulin requirement}

Figure 3. C-peptide positivity (>100 pmol/l in the fasting state) after long-term follow-up of simultaneous isletkidney transplantations 


\section{Kidney function}

Kidney function one year after combined transplantation was $70 \pm 23 \mathrm{ml} / \mathrm{min}$ and $50 \pm 20 \mathrm{ml} / \mathrm{min}$ in the SPK and SIK group, respectively. Whereas GFR did not differ between the two groups before renal transplantation, it was significantly different 1 year after transplantation $(\mathrm{p}<0.001)$. However, the decline of renal function of the transplanted kidney after SPK or SIK transplantation was not different between the two groups (Figure 4) at any time point during follow-up (Bonferroni correction applied, $\left.\alpha^{\prime}=0.004\right)$, with a decline of calculated GFR at year 13 after transplantation of $-9.5 \pm 23.3 \mathrm{ml} / \mathrm{min}(\mathrm{SPK})$ and $-13.3 \pm 13.8$ $\mathrm{ml} / \mathrm{min}$ (SIK) (ns). The percentage of patients with

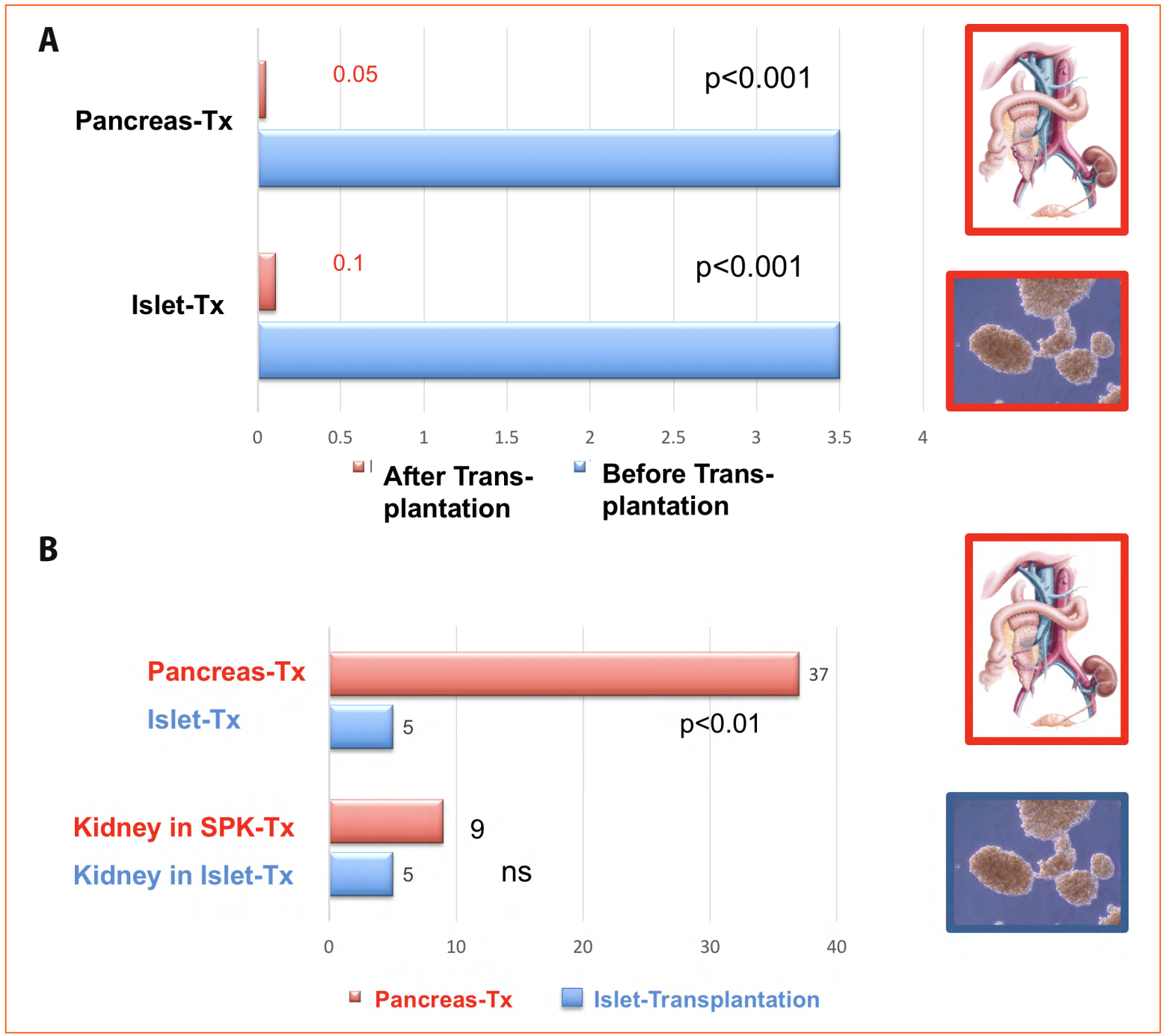

Figure 4. Severe episodes of hypoglycemia per 100 patient-years in a logarithmic scale (A) before and after (mean during follow-up) transplantation, and re-laparatomy rate due to kidney and pancreas or islet transplantation (B) during the first 3 months after transplantation in both patient groups (relaparotomy rate in red [pancreas transplantation] and blue [islet transplantation]); bars represent mean $\pm S D$

${ }^{*} p<0.05 ;{ }^{* * *} p<0.001$ (A, B: Mann-Whitney test, C: $X^{2}$ test) 
a change in CKD stage during follow-up was only $16 \%$ (SPK) and $8 \%$ (SIK) (ns).

In line with $\mathrm{HbA}_{1 \mathrm{c}}$ values, there was also no difference in kidney function at any time during follow-up between patients with a long ( $>10$ years) and short $(<10$ years) follow-up, when assessed separately for the SPK/PAK and SIK/IAK group.

Insulin requirement and occurrence of severe hypoglycemia after transplantation

Whereas insulin needed for diabetes therapy was not different between the two groups before transplantation $(\sim 0.5 \mathrm{U}$ per kg body weight), it differed significantly afterwards. Insulin dosage could be decreased in the SPK/PAK group by more than $80 \%$ (with most patients being insulin independent), but less than $20 \%$ in the SIK/IAK group (mean during follow-up) (Figure 5). However, the rate of severe hypoglycemia which was high and not different in both groups before transplantation $(346 \pm 445$ per 100 patient years in the whole cohort) dropped significantly to $5 \pm 15$ and $11 \pm 15$ per 100 patient years in the SPK/PAK and SIK/IAK groups, respectively (Figure 5).

\section{Procedure related complication rate, immunosuppression}

In SPK/PAK transplantation, the implanted pancreas had to be explanted in $10 \%$ (9 of 94 patients) due to complications. These included bleeding ( 2 cases) and vascular complications (thrombosis, 7 cases). A total of 39 patients (42\%) in this group underwent early (within 3 months) laparotomy, with $>1$ laparotomy in some patients (45 laparotomies in total) (Figure 5). The complications leading to early laparotomy included bleeding (13), thrombosis (7), ileus/volvulus (8), infection/pancreatitis (11), and others (2) as well as complications related to the transplanted kidney (4). In contrast, there were only 4 patients with need for relaparotomy in the SIK/IAK group (11\%) - two patients with a major bleeding at the site of hepatic vein puncture, and 2 patients with need for relaparotomy related to the transplanted kidney.

In contrast to the difference in total relaparotomy rate, there was no difference in the relaparotomy rate related to the kidney transplantation

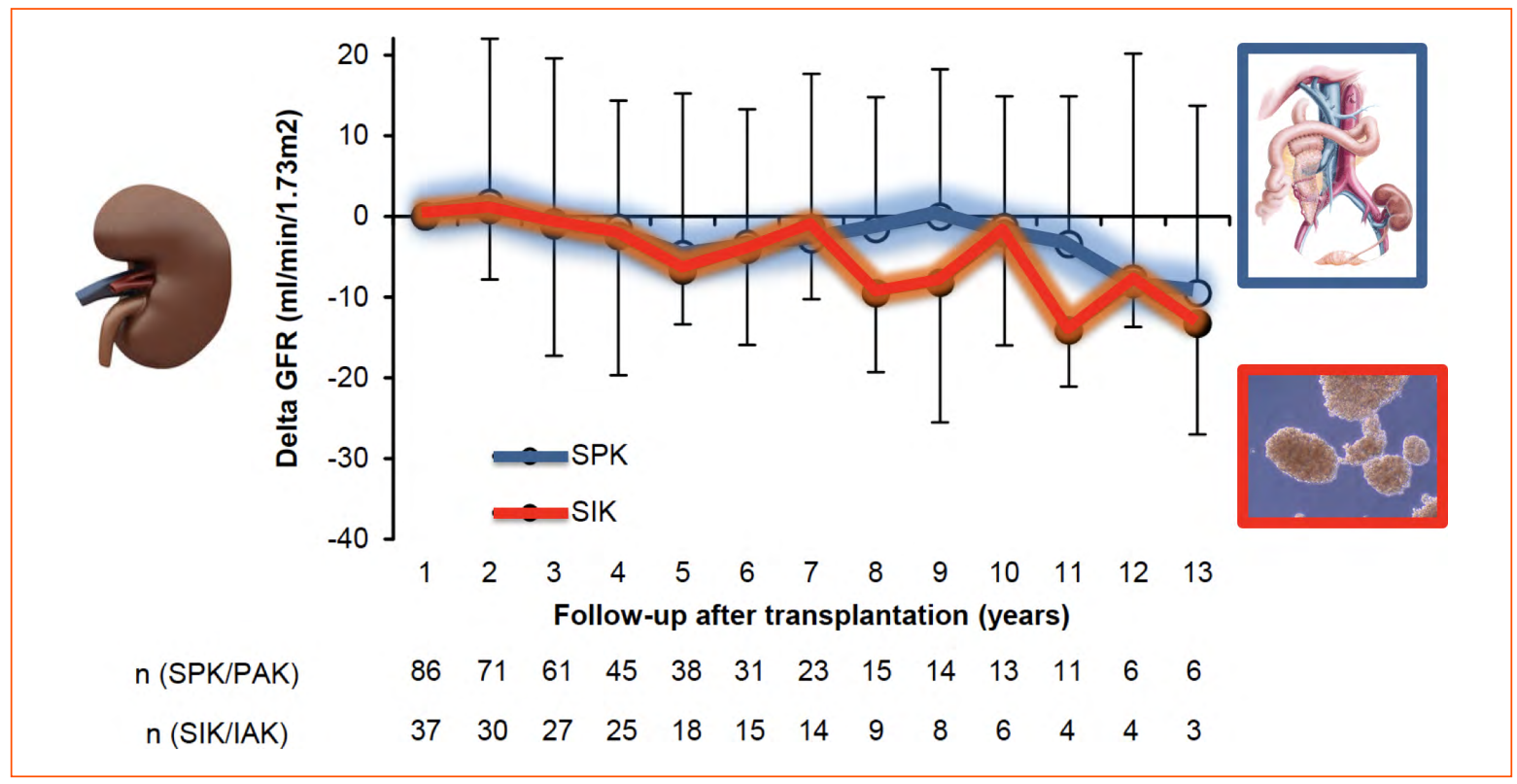

Figure 5. Change of calculated GFR ( $\left.\mathrm{ml} / \mathrm{min} / 1.73 \mathrm{~m}^{2}\right)$ after Simultaneous Pancreas-Kidney (SPK) or Simultaneous Islet-Kidney (SIK) transplantation after transplantation

$n$ : number of patients observed at a particular time point after transplantation

${ }^{*} p<0.004$ (Mann-Whitney test, Bonferroni correction applied, $a^{\prime}=0.004$ ) 
in the SPK and SIK groups (4\% and 5\%, respectively) (ns).

There was one case of death early after IAK transplantation due to cardiac arrest in a patient with a known history of coronary, cerebral and peripheral vascular disease after development of intrathoracic hemorrhage following islet transplantation.

\section{Cardiovascular risk factors, patient survival}

Body mass index was significantly higher in SIK/IAK recipients before, but not after transplantation

Table 2. Diabetes related complications and history of cardiovascular disease of patients included in the study

\begin{tabular}{|c|c|c|c|}
\hline & $\begin{array}{c}\text { SPK/PAK } \\
(\%)\end{array}$ & $\begin{array}{c}\text { SIK/IAK } \\
(\%)\end{array}$ & $\begin{array}{c}p- \\
\text { Value }\end{array}$ \\
\hline \multicolumn{4}{|c|}{ Retinopathy } \\
\hline None & 5 & 3 & \multirow{4}{*}{0.07} \\
\hline Non-proliferative & 16 & 8 & \\
\hline Proliferative & 66 & 58 & \\
\hline Amaurosis & 13 & 32 & \\
\hline \multicolumn{4}{|c|}{ Neuropathy } \\
\hline Peripheral & 83 & 92 & 0.17 \\
\hline Autonomic & 76 & 90 & 0.09 \\
\hline \multicolumn{4}{|c|}{ Coronary heart disease } \\
\hline None & 53 & 37 & \multirow{6}{*}{0.06} \\
\hline Asymptomatic & 10 & 3 & \\
\hline Symptomatic & 11 & 18 & \\
\hline Percutaneous intervention (PCI) & 16 & 13 & \\
\hline Myocardial infarction and PCI & 5 & 11 & \\
\hline Coronary artery bypass surgery & 5 & 18 & \\
\hline \multicolumn{4}{|c|}{ Cerebrovascular disease } \\
\hline None/not investigated & 86 & 76 & \multirow{4}{*}{0.35} \\
\hline Asymptomatic & 8 & 11 & \\
\hline Transient ischemic attack & 3 & 3 & \\
\hline Stroke & 3 & 11 & \\
\hline \multicolumn{4}{|c|}{ Peripheral vascular disease } \\
\hline None/not investigated & 53 & 47 & \multirow{6}{*}{0.52} \\
\hline Asymptomatic & 16 & 8 & \\
\hline Symptomatic & 8 & 16 & \\
\hline Percutaneous intervention (PCI) & 3 & 5 & \\
\hline Ulceration/gangrene & 4 & 3 & \\
\hline Amputation & 16 & 21 & \\
\hline
\end{tabular}

P-Values are calculated for comparison between groups ( $\mathrm{X} 2$ test). SPK: Simultaneous pancreas-kidney transplantation; PAK: pancreas after kidney transplantation; SIK: Simultaneous islet kidney transplantation; IAK: Islet after kidney transplantation
- BMI was significantly reduced after transplantation in this group, but not the SPK/PAK group. Both systolic and diastolic blood pressure declined significantly after transplantation in both groups, with a lower diastolic blood pressure in the SIK/IAK group.

10 -year patient survival was higher in the SPK/PAK group compared to the SIK/IAK group with $88.5 \%$ vs. $65.4 \%$, respectively $(\mathrm{p}=0.04)$, due to younger age and less cardiovascular complications at baseline (Table 1 and 2).

\section{Prevention of severe hypoglycemia by beta-cell replacement therapy}

This review describes the comparison of the different methods for beta-cell replacement and the avoidance of severe hypoglycemia and it includes the first prospective cohort study directly comparing the outcome of patients undergoing pancreas or islet transplantation (simultaneously with or after a kidney transplantation) during a long-term follow-up of more than 10 years.

There are differences between the two treatment options of beta-cell replacement that preclude a randomized trial in order to compare the two methods within similar patient groups, e.g. the more invasive character of whole-organ transplantation, which favors whole-organ transplantation in younger patients with fewer comorbidities. SPK/PAK recipients were younger at the time of transplantation, and duration of diabetes was shorter before transplantation. Further, there was a tendency towards a higher rate of diabetes related complications as well as cardiovascular disease in the SIK/IAK group (Table 1 and 2).

The rate of insulin independence was higher in whole organ recipients compared to islet recipients, and comparable to the results of current analyses of the International Pancreas Transplant Registry. ${ }^{10}$ If insulin independence is the aim of islet transplantation, multiple islet infusions are common. ${ }^{11}$ However, the aim of the transplantation program in Zurich with double organ recipients is to achieve glucose stability providing protection from further organ damage caused by hyperglycemia (in particular deterioration of the function of the transplanted kidney) without the 
occurrence of severe hypoglycemia, which is a major problem before transplantation. Such reduction of hypoglycemia was achieved in both groups after transplantation, with the number of severe hypoglycemia per year that was not only significantly lower compared to the situation before transplantation, but also compared to patients treated with intensified insulin therapy. ${ }^{25}$ Improvement and stability of glucose control after transplantation could be demonstrated throughout the whole follow-up, with a slightly higher $\mathrm{HbA}_{1 \mathrm{c}}$ concentration in the islet transplantation group. C-peptide remained stable during the first years after islet transplantation, with some decline after year 6 . Sustained positive C-peptide response itself (Figure 3$)^{30}$ may be of importance regarding diabetes associated complications, given the increasing evidence of positive effects of $\mathrm{C}$-peptide regarding vascular, renal and nerve dysfunction. . $^{31,32,33}$

Both groups showed an $\mathrm{HbA}_{1 \mathrm{c}}$ concentration which was lower than what was shown in patients treated with intensified insulin therapy. ${ }^{25,34}$ However, the transplanted islet mass seems sufficient to provide enough insulin to compensate for inadequately injected amounts of insulin to ensure good glycemic control without severe hypoglycemia. Further, the difference in insulin need before and after transplantation may be underestimated since insulin requirement before transplantation is reduced due to renal failure, at least in those patients with simultaneous transplantation. ${ }^{35}$

Prednisone was used in pancreas transplant recipients, but since it could be tapered off in most patients during the first 2-3 years of follow-up or at least be reduced to low dosages, a relevant impact on glycemic control is unlikely.

When assessed one year after combined transplantation, renal function was significantly lower in SIK recipients compared to SPK recipients, which is most probably attributable to differences in donor age. ${ }^{36}$ It should be noted that there was no difference in the rate of decline of renal function between the two groups. In a recent study, SPK transplantation has been shown to preserve longterm kidney graft function better than transplantation of a kidney alone. ${ }^{37}$ The lack of a difference in the decline of kidney function between the two groups in our study as compared to SPK recipients vs. patients with a life-donated kidney transplant alone reported in Sweden ${ }^{37}$ suggests that positive effects of improved glycemic control on kidney function could be relevant for both forms of betacell replacement therapy (Figure 6).

The relaparotomy rate early after transplantation (during the first three months) was higher in SPK/PAK recipients compared to SIK/IAK

Table 3. Cardiovascular risk factors before and after transplantation

\begin{tabular}{|c|c|c|c|c|}
\hline & & SPK/PAK & SIK/IAK & $p$-Value \\
\hline \multirow{2}{*}{$\mathrm{BMI}\left(\mathrm{kg} / \mathrm{m}^{2}\right)$} & Before transplantation & $23 \pm 3$ & $25 \pm 4$ & 0.02 \\
\hline & After transplantation & $23 \pm 4$ & $24 \pm 4^{*}$ & 0.43 \\
\hline \multirow{2}{*}{ Systolic blood pressure $(\mathrm{mmHg})$} & Before transplantation & $145 \pm 25$ & $149 \pm 20$ & 0.24 \\
\hline & After transplantation & $140 \pm 16^{*}$ & $138 \pm 15^{*}$ & 0.98 \\
\hline \multirow{2}{*}{ Diastolic blood pressure $(\mathrm{mmHg})$} & Before transplantation & $83 \pm 12$ & $82 \pm 11$ & 0.73 \\
\hline & After transplantation & $79 \pm 8^{*}$ & $74 \pm 9 *$ & 0.005 \\
\hline \multirow{2}{*}{ Total cholesterol (mmol/l) } & Before transplantation & $4.6 \pm 1.2$ & $4.7 \pm 1.2$ & 0.30 \\
\hline & After transplantation & $4.3 \pm 0.8$ & $4.5 \pm 1.1$ & 0.40 \\
\hline \multirow{2}{*}{ HDL cholesterol (mmol/l) } & Before transplantation & $1.6 \pm 0.5$ & $1.5 \pm 0.6$ & 0.55 \\
\hline & After transplantation & $1.5 \pm 0.4$ & $1.4 \pm 0.5$ & 0.35 \\
\hline \multirow{2}{*}{ LDL cholesterol (mmol/l) } & Before transplantation & $2.3 \pm 1.0$ & $2.6 \pm 0.9$ & 0.15 \\
\hline & After transplantation & $2.2 \pm 0.8$ & $2.2 \pm 0.7$ & 0.71 \\
\hline \multirow{2}{*}{ Triglycerides (mmol/l) } & Before transplantation & $1.4 \pm 0.8$ & $1.5 \pm 0.8$ & 0.50 \\
\hline & After transplantation & $1.4 \pm 0.8$ & $1.5 \pm 0.7$ & 0.16 \\
\hline
\end{tabular}

Data are provided as mean \pm SD. P-Values (last column) are calculated for comparison between groups.

SPK: simultaneous pancreas-kidney transplantation; PAK: pancreas after kidney transplantation; SIK: simultaneous islet kidney transplantation; IAK: islet after kidney transplantation

${ }^{*} \mathrm{p}<0.05$ for difference before and after transplantation (Mann-Whitney test) 


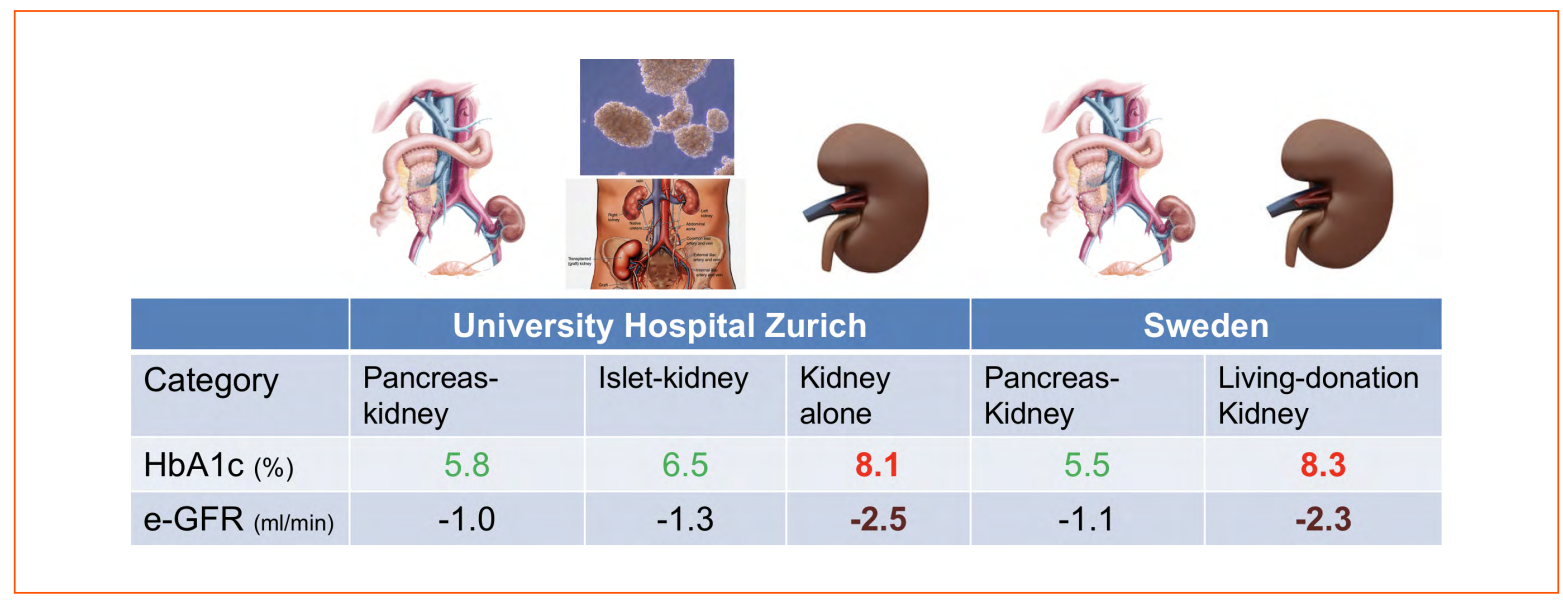

Figure 6. $H b A_{1 c}$ and the decrease in e-GFR $(\mathrm{ml} / \mathrm{min} /$ year) in the simultaneous pancreas-kidney and islet kidney group vs. kidney transplantation alone in the University Hospital Zürich (left) and between simultaneous pancreas-kidney and kidney transplantation alone (with life organ donation) in Sweden (right)

transplantation (Figure 5), and similar to the rate that was reported recently by Page et al. ${ }^{13}$ In contrast to the overall relaparotomy rate, the laparotomies that were caused by complications at the site of the kidney transplantation was not different between groups, indicating that transplantation of the pancreas was the main reason of an increased complication rate in the whole organ transplantation group. Whereas bleeding was the only type of complication in the SIK/IAK group, the type of complication varied widely in the SPK/PAK group.

As expected, 10-year mortality was significantly higher in the SIK/IAK group. A variety of factors may have contributed to this difference. First, SIK/IAK patients were more than 7 years older. The comparison of similar age categories as assessed by this study within the general population in Switzerland shows an increased mortality (2.3 fold). Further, the tendency towards an increased prevalence and severity of cardiovascular disease may have reduced survival in the SIK/IAK group. In the whole cohort, patients with coronary heart disease exhibited a significantly higher mortality than those without coronary heart disease (66\% vs. $85 \%$ 10-year patient survival, respectively, $p=0.03$ ). Finally, the difference in diabetes duration before transplantation may have contributed independently to the increased mortality in the SIK/IAK group.
The main advantages of this study are the relatively high number of patients, the length of follow-up and the interdisciplinary care for the patients by the same team during follow-up.

In conclusion, our data of a long-term followup provides evidence that both the combination of kidney transplantation with a pancreas as well as with isolated islets result in significant and sustained improvement of glucose control without the occurrence of severe hypoglycemia. While insulin independence is more common in whole organ pancreas recipients, islet transplantation can be conducted with a lower complication rate. Although the glycated hemoglobin is slightly lower and the insulin independence rate higher in the SPK/PAK group, there is no difference in the decline of kidney function between the two groups for more than ten years. This is the first description that with regard to maintenance of a good kidney function, islet transplantation is not inferior to pancreas transplantation.

A careful selection of the adequate procedure by interdisciplinary transplantation teams may help to ensure optimal care for patients with diabetes undergoing combined transplantation. 


\section{References}

1. Somogyi M: Effect of insulin hypoglycemia on alimentery hyperglycemia. J Biol Chem 1951; 193: 859-871.

2. Choudari P, Davies C, Emery C, Heller R: Do high fasting glucose levels suggest noc-turnal hypoglycaemia? The Somogyi effect - more fiction than fact? Diabetic Medicine 2013; 30(8): 914-917. doi:10.1111/dme.12175

3. Kelly WD, Lillehei RC, Merkel FK, Idezuki Y, Goetz FC: Allotransplantation of the pancreas and duodenum along with the kidney in diabetic nephropathy. Surgery 1967; 61(6): 827-837.

4. Shapiro AM, Lakey JR, Ryan EA, Korbutt GS, Toth E, Warnock GL, et al: Islet transplantation in seven patients with type 1 diabetes mellitus using a glucocorticoid-free immunosuppressive regimen. $\mathrm{N}$ Engl J Med 2000; 343(4): 230-238. doi:10.1056/NEJM200007273430401

5. Sutherland DE: Pancreas and islet transplantation. II. Clinical trials. [Review]. Diabetologia 1981; 20(4): 435-450. doi:10.1007/BF00253405

6. Luzi L, Hering BJ, Socci C, Raptis G, Battezzati A, Terruzzi I, et al:: Metabolic effects of successful intraportal islet transplantation in insulin-dependent diabetes mellitus. I Clin Invest J1 - JCI 1996; 97(11): 2611-2618. doi: $10.1172 / \mathrm{JCl} 118710$

7. 0jo AO, Meier-Kriesche HU, Hanson JA, Leichtman A, Magee JC, Cibrik $D$, et al: The impact of simultaneous pancreas-kidney transplantation on long-term patient survival. Transplantation 2001; 71(1): 82-90. doi:10.1097/00007890-200101150-00014

8. Gruessner RW, Sutherland DE, Gruessner AC: Mortality assessment for pancreas transplants. Am I Transplant 2004; 4(12): 2018-2026. doi:10.1111/j.1600-6143.2004.00667.x

9. Venstrom JM, McBride MA, Rother KI, Hirshberg B, Orchard TJ, Harlan DM: Survival after pancreas transplantation in patients with diabetes and preserved kidney function. JAMA 2003; 290(21): 2817-2823. doi:10.1001/jama.290.21.2817

10. Gruessner RW, Gruessner AC: The current state of pancreas transplantation. Nat Rev Endocrinol 2013; 9(9): 555-562. doi:10.1038/nrend0.2013.138

11. Shapiro AM, Ricordi C, Hering BJ, Auchincloss H, Lindblad R, Robertson RP, et al.: International trial of the Edmonton protocol for islet transplantation. N Engl J Med 2006; 355(13): 1318-1330. doi:10.1056/NEJMoa061267

12. Bellin MD, Barton FB, Heitman A, Harmon JV, Kandaswamy R, Balamurugan AN, et al.: Potent Induction Immunotherapy Promotes Long-Term Insulin Independence After Islet Transplantation in Type 1 Diabetes. Am J Transplant 2012; 12: 1576-1583. doi:10.1111/j.1600-6143.2011.03977.x

13. Page M, Rimmele T, Ber CE, Christin F, Badet L, Morelon E, et al.: Early relaparotomy after simultaneous pancreas-kidney transplantation. Transplantation 2012; 94(2): 159-164. doi:10.1097/TP.0b013e318254dae1

14. Gerber PA, Pavlicek V, Demartines N, Zuellig R, Pfammatter T, Wuthrich R, et al.: Simultaneous islet-kidney vs. pancreas-kidney transplantation in type 1 diabetes mellitus: a 5 year single centre follow-up. Diabetologia 2008; 51 (1): 110-119. doi:10.1007/s00125-007-0860-4

15. Maffi P, Scavini M, Socci C, Piemonti L, Caldara R, Gremizzi C, et al.: Risks and benefits of transplantation in the cure of type 1 diabetes: whole pancreas vs. islet transplantation. A single center study. Rev Diabet Stud 2011; 8(1): 44-50. doi:10.1900/RDS.2011.8.44

16. Largiader $F$, Kolb E, Binswanger U: A long-term functioning human pancreatic islet allotransplant. Transplantation 1980; 29: 76-77. doi:10.1097/00007890-198001000-00017

17. Ricordi C, Lacy PE, Finke EH, Olack BJ, Scharp DW: Automated method for isolation of human pancreatic islets. Diabetes 1988; 37: $413-420$. doi:10.2337/diab.37.4.413
18. Lehmann R, Weber M, Berthold P, Zullig R, Pfammatter T, Moritz W, et al: Successful simultaneous islet-kidney transplantation using a steroid-free immunosuppression: two-year follow-up. Am J Transplant 2004; 4(7): 1117-1123. doi:10.1111/j.1600-6143.2004.00468.x

19. Ricordi C, Gray DW, Hering BJ, Kaufman DB, Warnock GL, Kneteman NM, et al.: Islet isolation assessment in man and large animals. Acta Diabetol Lat 1990; 27(3): 185-195. doi:10.1007/BF02581331

20. Land W, Malaise J, Sandberg J, Langrehr J, Group ES: Tacrolimus vs. cyclosporine in primary simultaneous pancreas-kidney transplantation: preliminary results at 1 year of a large multicenter trial. Transplant Proc 2002; 34(5): 1911-1912. doi:10.1016/50041-1345(02)03120-2

21. Merion RM, Henry ML, Melzer JS, Sollinger HW, Sutherland DE, Taylor RJ: Randomized, prospective trial of mycophenolate mofetil vs. azathioprine for prevention of acute renal allograft rejection after simultaneous kidneypancreas transplantation. Transplantation 2000; 70(1): 105-111.

22. Bazerbachi F, Selzner M, Boehnert MU, Marquez MA, Norgate A, McGilvray ID, et al:. Thymoglobulin vs. basiliximab induction therapy for simultaneous kidney-pancreas transplantation: impact on rejection, graft function, and long-term outcome. Transplantation 2011; 92(9): 1039-1043. doi:10.1097/TP.0b013e3182313e4f

23. Matsumoto S, Takita M, Chaussabel D, Noguchi H, Shimoda M, Sugimoto $\mathrm{K}$, et al.: Improving efficacy of clinical islet transplantation with iodixanolbased islet purification, thymoglobulin induction, and blockage of IL-1beta and TNF-alpha. Cell Transplant 2011; 20(10): 1641-1647. doi: $10.3727 / 096368910 \times 564058$

24. Levey AS, Stevens LA, Schmid CH, Zhang YL, Castro AF, 3rd, Feldman HI, et al: A new equation to estimate glomerular filtration rate. Ann Intern Med 2009; 150(9): 604-612. doi:10.7326/0003-4819-150-9-200905050-00006

25. The DCCT Research Group: The effect of intensive treatment of diabetes on the development and progression of long-term complications in insulin-dependent diabetes mellitus. The Diabetes Control and Complications Trial Research Group. N Engl J Med 1993; 329(14): 977-986. doi:10.1056/NEJM199309303291401

26. Choudhary P, Rickels MR, Senior PA, Vantyghem M-C, Maffi P, Kay TW, et al.: Evidence-Informed Clinical Practice Recommendations for Treatment of Type 1 Diabetes Complicated by Problematic Hypoglycemia. Diabetes Care 2015; 38(6): 1016-1029. doi:10.2337/dc15-0090

27. Gerber PA, Pavlicek V, Demartines N, Zuellig R, Pfammatter T, Wüthrich R, et al.: Simultaneous islet-kidney vs. pancreas-kidney transplantation in type 1 diabetes mellitus: a 5 year single centre follow-up. Diabetologia 2008; 51 (1): 110-119. doi:10.1007/s00125-007-0860-4

28. Lehmann R, Spinas GA, Moritz W, Weber M: Has Time Come for New Goals in Human Islet Transplantation? Am J Transplant 2008; 8(6): 1096-1100. doi:10.1111/j.1600-6143.2008.02214.x

29. Lehmann R, Graziano J, Brockmann J, Pfammatter T, Kron P, de Rougemont 0 , et al: Glycemic Control in Simultaneous Islet-Kidney Versus PancreasKidney Transplantation in Type 1 Diabetes: A Prospective 13-Year Follow-up. Diabetes Care 2015; 38(5): 752-759. doi:10.2337/dc14-1686

30. Gerber PA, Lehmann R. Inseltransplantation zur Behandlung des Diabetes mellitus Typ 1. Der Diabetologe 2015; 11(7): 545-552.

31. Bhatt MP, Lim YC, Hwang J, Na S, Kim YM, Ha KS: C-peptide prevents hyperglycemia-induced endothelial apoptosis through inhibition of reactive oxygen species-mediated transglutaminase 2 activation. Diabetes 2013; 62(1): 243-253. doi:10.2337/db12-0293

32. Ekberg $K$, Brismar $T$, Johansson BL, Lindstrom $P$, Juntti-Berggren $L$, Norrby A, et al: (-Peptide replacement therapy and sensory nerve function in type 1 diabetic neuropathy. Diabetes Care 2007; 30(1): 71-76. doi:10.2337/dc06-1274 
33. Wahren J, Kallas A, Sima AA: The clinical potential of C-peptide replacement in type 1 diabetes. Diabetes 2012; 61(4): 761-772 doi:10.2337/db11-1423

34. Nathan DM, Group DER: The diabetes control and complications trial/ epidemiology of diabetes interventions and complications study at 30 years: overview. Diabetes Care 2014; 37(1): 9-16. doi:10.2337/dc13-2112

35. Biesenbach G, Raml A, Schmekal B, Eichbauer-Sturm G: Decreased insulin requirement in relation to GFR in nephropathic Type 1 and insulintreated Type 2 diabetic patients. Diabet Med 2003; 20(8): 642-645. doi:10.1046/j.1464-5491.2003.01025.x

36. Rao KV, Kasiske BL, Odlund MD, Ney AL, Andersen RC: Influence of cadaver donor age on posttransplant renal function and graft outcome. Transplantation 1990; 49(1): 91-95. doi:10.1097/00007890-199001000-00020

37. Lindahl JP, Reinholt FP, Eide IA, Hartmann A, Midtvedt $K$, Holdaas $H$, et al.: In patients with type 1 diabetes simultaneous pancreas and kidney transplantation preserves long-term kidney graft ultrastructure and function better than transplantation of kidney alone. Diabetologia 2014; $57(11)$ : 2357-2365. doi:10.1007/s00125-014-3353-2
Közlésre érkezett: 2018. július 20.

Közlésre elfogadva: 2018, augusztus 30.

\section{A szerzö levelezési címe:}

\section{Roger Lehmann}

Director Diabetology and Islet Transplantation Program

Department for Endocrinology, Diabetes, and Clinical Nutrition, University Hospital Zurich

Raemistrasse 100

$\mathrm{CH}-8091$ Zurich, Switzerland

E-mail: roger.lehmann@usz.ch 